\title{
Studi Pengembangan Desain Motif Batik Tulis Lasem Rembang
}

\author{
Nabila Disarifianti ${ }^{1}$, Didit Prasetyo ${ }^{2}$ \\ ${ }^{1,2}$ Desain Komunikasi Visual, Institut Teknologi Sepuluh Nopember, Gedung Desain, Kampus ITS Surabaya, \\ Indonesia, 60111
}

Correspondence: Didit Prasetyo (didit@its.ac.id)

Received: 140621 - Revised: DD MMYY - Accepted: DD MM YY - Published: DD MM YY

\begin{abstract}
Abstrak. Batik tulis Lasem telah menjadi salah satu identitas asli Kabupaten Rembang, Jawa Tengah sejak masa lampau. Kota asal batik Lasem memiliki pengaruh dari budaya etnis Tionghoa sehingga motif batik Lasem itu sendiri merupakan hasil akulturasi budaya lokal dengan budaya Tionghoa. Hal ini ditunjukkan dengan adanya motif khas budaya Tionghoa seperti naga, burung hong, dan bunga teratai, namun tetap mempertahankan unsur budaya lokal berupa warna-warna klasik khas Lasem. Tujuan dari penelitian pengembangan ini adalah untuk mengeksplorasi kebudayaan secara positif yang menyesuaikan dengan perkembangan jaman yang lebih modern, khususnya pada generasi milenial sehingga kelestarian budaya nusantara tetap terjaga. Metode penelitian bersifat kualitatif deskriptif dengan pendekatan berupa studi literatur. Melalui penelitian pengembangan ini akan menghasilkan desain motif batik Lasem yang sudah diperbarui dan dikembangkan menjadi lebih modern tanpa menghilangkan esensi serta nilai budaya dalam seni kerajinan batik tersebut. Pengembangan desain motif meliputi penyerderhanaan elemen pada batik serta pemilihan komposisi warna yang lebih menarik.
\end{abstract}

kata kunci : motif, budaya, batik tulis, lasem

Citation Format: Disarifianti, N., Prasetyo, D. (2020). Studi Pengembangan Desain Motif Batik Tulis Lasem Rembang. Prosiding Seminar Nasional Abdimas Ma Chung (SENAM), 2020, xx-xx. 


\section{PENDAHULUAN}

Batik merupakan salah satu warisan budaya Indonesia yang sudah cukup dikenal secara global. Dalam perjalanannya, batik sebagai hasil tradisi dan ekspresi budaya terus berkembang mengikuti pertumbuhan jaman. Kain batik yang semula hanya untuk kebutuhan sandang kini perannya menjadi lebih luas, yakni memiliki pengaruh besar terhadap kehidupan sosial budaya dan dapat menggerakkan perekonomian masyarakat. Berdasarkan data Kementerian Perindustrian, nilai ekspor batik pada awal tahun 2020 mencapai USD 21,54 juta atau setara Rp321 miliar dan menjadi penyumbang yang cukup besar bagi devisa negara. Hal ini membuktikan bahwa tidak hanya bergerak di bidang budaya, batik juga memberikan kontribusi bagi pertumbuhan sektor ekonomi di Indonesia.

Batik muncul dan berkembang di berbagai wilayah di tanah air, terutama di wilayah pedalaman Pulau Jawa. Salah satu batik yang tumbuh di Jawa adalah Batik Lasem. Batik tulis Lasem telah menjadi salah satu identitas asli Kabupaten Rembang, Jawa Tengah sejak masa lampau. Kota asal batik Lasem memiliki pengaruh dari budaya etnis Tionghoa sehingga motif batik Lasem itu sendiri merupakan hasil akulturasi budaya lokal dengan budaya Tionghoa. Hal ini dikarenakan Lasem merupakan wilayah awal pendaratan orang Tionghoa di Pulau Jawa. Terbentuknya komunitas Tionghoa di Lasem diawali dengan terbinanva hubungan dagang antara kerajaan Tiongkok dengan kerajaan-kerajaan di Nusantara sekitar awal abad ke-5 Masehi (Hasanudin, 2001). Di tengah kegiatan perdagangannya, Bangsa Tionghoa mulai ikut serta dalam usaha industri batik Lasem milik pribumi. Pada awalnya, pengusaha batik Tionghoa hanya memproduksi batik untuk kalangan keluarga saja, namun karena permintaan konsumen yang cukup tinggi batik Tionghoa akhirnya bisa menguasai pasar (Maulany \& Masruroh, 2017)

Sebelum kedatangan bangsa Tionghoa, batik Lasem itu sendiri sudah ada sejak abad ke-13 dan digunakan oleh kaum bangsawan di Lasem. Batik Lasem asli memiliki warna khas cokelat dan biru tua, yang dikenal dengan Sogan Majapahit. Semenjak kedatangan bangsa Tionghoa, motif batik Lasem kini lebih didominasi dengan motif-motif berciri khas budaya Tionghoa yang ditunjukkan dengan adanya elemen naga, burung hong, dan bunga teratai. Warna kain batik Lasem juga bukan cokelat dan biru tua lagi, namun kini lebih didominasi oleh warna merah atau getih pitik yang berarti darah ayam.

Industri kain Batik merupakan komoditi yang memiliki daya tarik yang cukup besar bagi konsumen. Kain batik kini tidak hanya digunakan untuk pakaian saja, namun bisa menjadi produk-produk dengan utilitas dan estetika yang tinggi, sehingga dapat menjadi 
lifestyle baru bagi masyarakat dalam rangka mengenal dan mencintai produk buatan negeri. Peningkatan nilai tambah ekonomi pada industri batik dapat dilakukan dengan melakukan inovasi dan beradaptasi dengan perkembangan jaman. Salah satu upaya yang dapat dilakukan adalah dengan melakukan pengembangan motif atau ornamen pada batik.

Pengembangan produk batik melalui perekayasaan desain motif batik memiliki peranan penting dan ikut menentukan keberhasilan produk batik. Peran desain dalam keberhasilan produk tersebut sangat besar di samping faktor ekonomi dan manajemen (Murwati \& Masiswo, 2013). Dalam penelitian pengembangan ini, motif batik tulis Lasem menjadi salah satu contoh yang layak untuk digali dan dikembangkan menjadi desain motif baru yang lebih modern modern tanpa menghilangkan esensi serta nilai budaya dalam seni kerajinan batik Lasem itu sendiri. Penciptaan desain motif batik Lasem yang diperbarui harus memiliki peran dalam meningkatkan daya saing yang didasari oleh kriteria nilai fungsi, estetika, dan inovasi. Penelitian pengembangan batik tulis Lasem ini bertujuan untuk mengeksplorasi kebudayaan secara positif yang menyesuaikan dengan perkembangan jaman yang lebih modern, khususnya pada generasi milenial sehingga kelestarian budaya nusantara tetap terjaga.

\section{METODE PELAKSANAAN}

Metode yang digunakan dalam penelitian pengembangan ini adalah kualitatif deskriptif dengan pendekatan studi literatur dan pengumpulan moodboard untuk dijadikan referensi visual. Metode studi literatur digunakan untuk menemukan data yang bersifat kualitatif. Data didapatkan melalui berbagai referensi jurnal, laporan penelitian, artikel, serta situs-situs internet guna mengkaji penelitian - penelitian terdahulu dengan topik yang serupa agar dapat ditarik kesimpulan yang bersifat lebih luas dan mendalam. Selain itu juga untuk menambah wawasan mengenai kebudayaan Indonesia yang salah satunya adalah kerajinan batik.

Desain motif batik lokal tersebut dikaji lebih lanjut dan dikumpulkan bersama desain motif yang lebih modern sebagai moodboard untuk dijadikan referensi visual bagi pengembangan desain motif batik. Menurut (Anggarini et al, 2020), moodboard adalah mekanisme yang digunakan untuk merespon persepsi tentang permasalahan dan ide yang akan dikembangkan. Kontstruksi moodboard memiliki potensi untuk menstimulasi persepsi dan interpretasi dari warna, tekstur, bentuk, gambar, dan status (Garner, 2011). 
Langkah selanjutnya adalah menyusun konsep desain dengan mengkombinasikan motif batik Lasem dengan desain motif modern yang diminati pasar. Hal ini dilakukan dengan melakukan penyederhanaan elemen motif batik Lasem tanpa menghilangkan ornamen khasnya. Setelah itu memasuki proses pembuatan motif yang sudah dikembangkan. Alur proses penelitian pengembangan motif batik tulis Lasem adalah sebagai berikut :

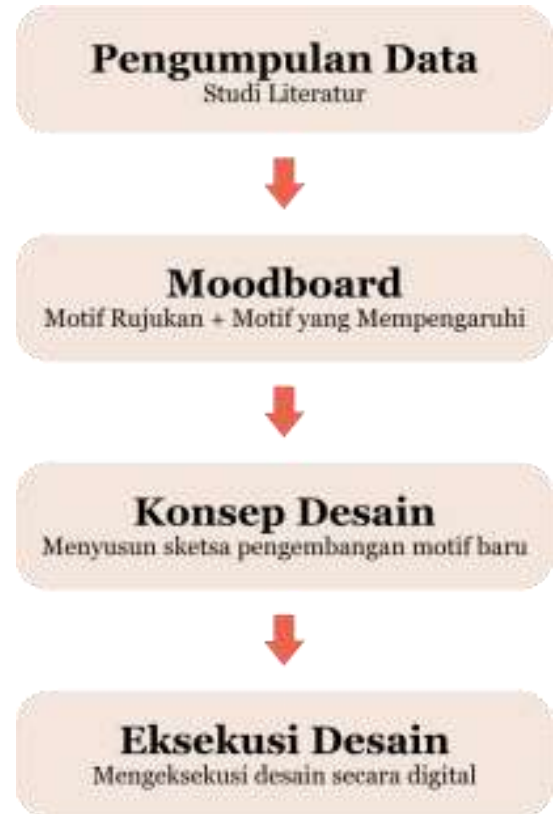

Gambar 1 : Diagram Alur Penelitian Pengembangan Motif Batik Tulis Lasem

\section{HASIL DAN PEMBAHASAN}

\section{Analisis Ornamen Batik Tulis Lasem}

Batik tulis Lasem memiliki harga yang relative mahal karena dikenal dengan kerumitan motifnya. Batik Lasem memiliki pola dan corak khas tersendiri dengan paduan warna yang berani dan mencolok serta dengan motif dan ornamen yang beraneka ragam. Berbeda dengan batik Yogyakarta dan Solo yang sangat baku terhadap pakem keraton dan hanya digunakan khusus bagi golongan ningrat karena motifnya yang eksklusif, batik Lasem lebih bercirikan egalitarian, yakni lebih terbuka untuk umum, dimana penggunaannya terbuka bagi segala kalangan atau lapisan masyarakat yang berasal dari berbagai etnis (Unjiya, 2008).

Sama seperti motif batik wilayah lain di Indonesia, motif batik Lasem memiliki makna dan simbol-simbol yang mengandung harapan tertentu dari pembuatnya. Keberadaan motif atau simbol tersebut dipercaya oleh masyarakat setempat memiliki daya 
magis yang diharapkan dapat mensugesti pemakai kain untuk senantiasa berpikir positif, bertindak benar, bertambah bijaksana, dan masih banyak lagi (Maulany \& Masruroh, 2017). Arti atau filosofi dibalik setiap motif kain berbeda tergantung dengan elemen yang ada pada batik Lasem. Sebagai contoh, motif kupu-kupu (hu-die) memiliki makna keceriaan dan harapan panjang usia ; motif naga (liong) menyimbolkan lelaki, pembawa kesejahteraan dan kebahagiaan ; dan burung merak (kong-que) yang bermakna kecantikan dan kemuliaan.

Apabila dilihat dari segi warna, batik Lasem memiliki ciri khas warna merah gelap yang didapatkan secara alami, yakni dipengaruhi oleh air tanah yang mengandung mineral tertentu dan hanya terdapat di daerah Lasem. Berbagai warna pada batik Lasem juga mengandung makna-makna ternetu seperti warna merah (hong) yang berarti kegembiraan dan kekayaan serta ungu ( $z i)$ yang bermakna ketenangan dan loyalitas.

Batik Lasem memiliki lebih dari 20 jenis motif yang memiliki keunikan tersendiri. Berikut adalah beberapa contoh motif batik Lasem yang cukup terkenal.

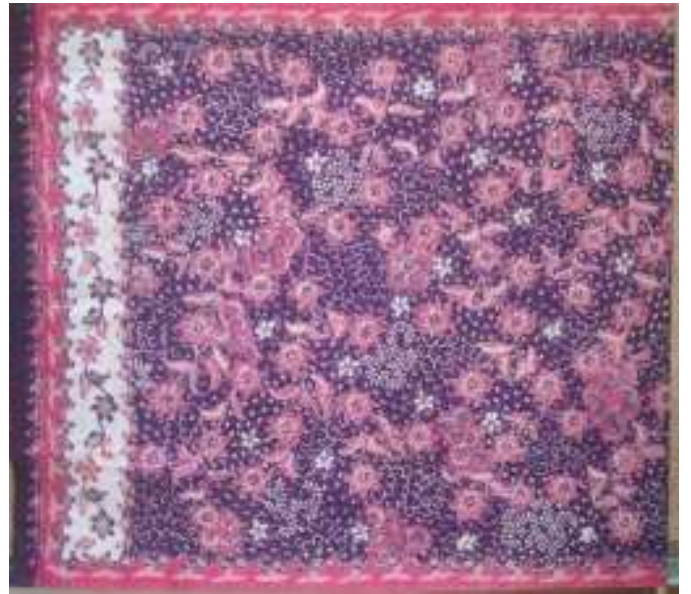

Gambar 2 : Batik Lasem Sekar Jagad

Sumber : https://batiktulislasem.com/batik-lasem-sekar-jagad-tumpal-bta-0067/batik-lasem-sekarjagad-pink-ungu-tumpal/

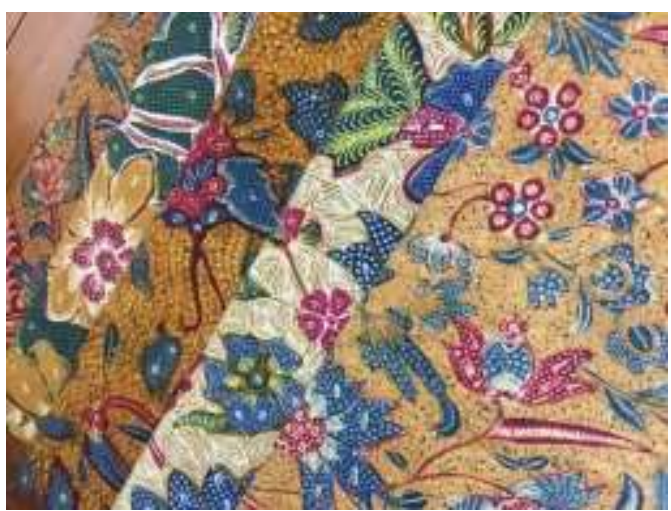


Gambar 4 : Batik Lasem Tiga Negeri

Sumber : https://inibaru.id/tradisinesia/batik-tiga-negeri-keluarga-tjoa-mahakarya-peranakantionghoa-dengan-pewarnaan-dari-tiga-kota

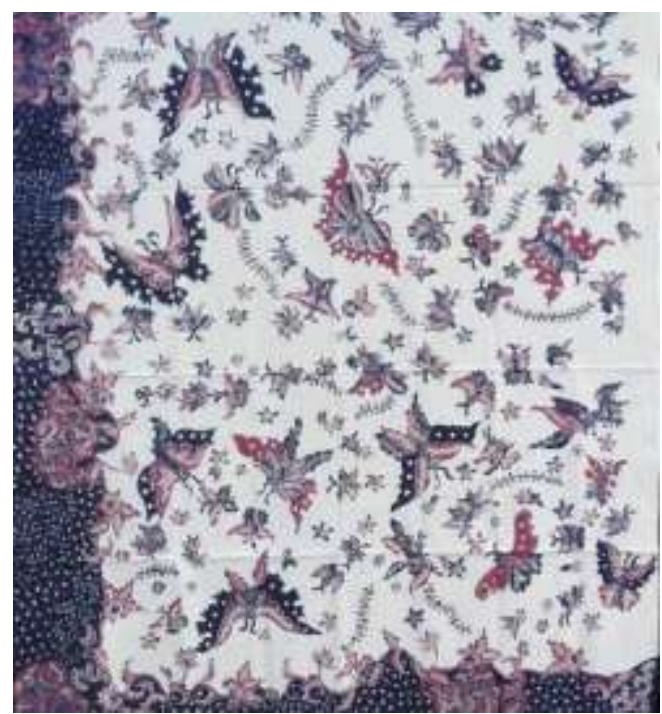

Gambar 5 : Batik Lasem Bledak Kupu-Kupu

Sumber : http://batiktulislasem.com/batik-tulis-lasem-kupu-kupu-btls-015/

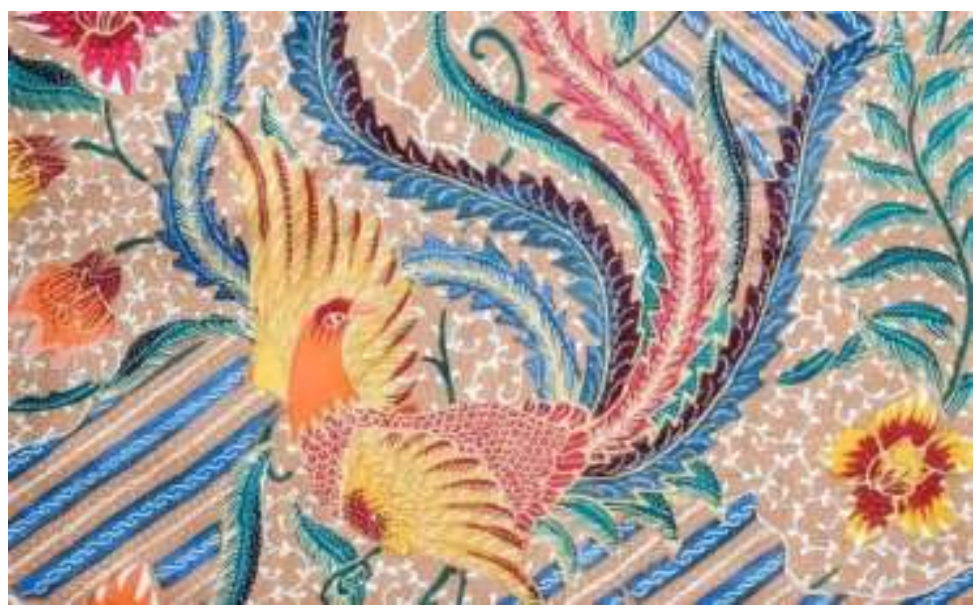

Gambar 6 : Batik Lasem Burung Hong

Sumber : https://inibaru.id/tradisinesia/batik-tiga-negeri-keluarga-tjoa-mahakarya-peranakantionghoa-dengan-pewarnaan-dari-tiga-kota

\section{Proses Pengembangan Motif Batik Tulis Lasem}

1) Menyusun Moodboard

Moodboard disusun untuk menjadikan referensi visual terpetakan dengan jelas, sehingga pembuatan konsep desain dapat menjadi lebih mudah. Berikut adalah moodboard batik tulis Lasem yang dijadikan sebagai motif rujukan utama. 


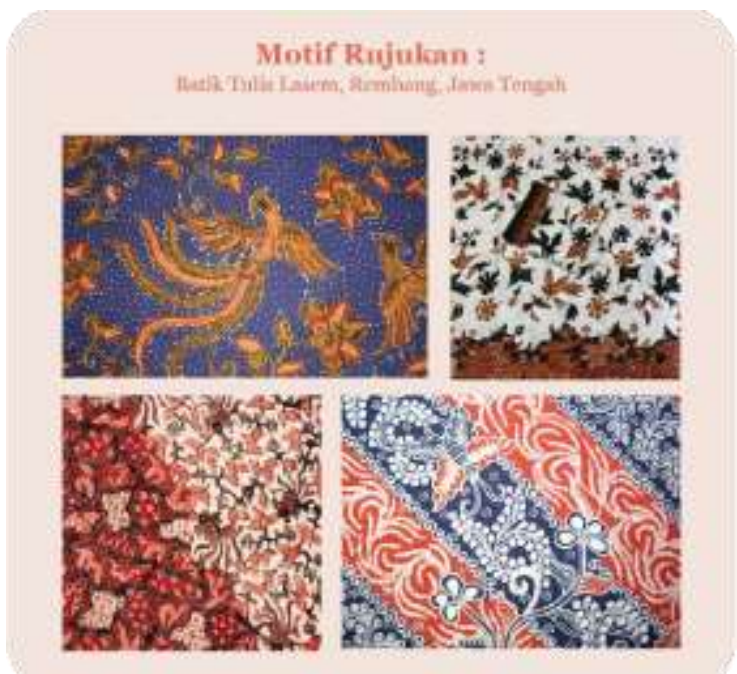

Gambar 7 : Moodboard Batik Tulis Lasem Sebagai Motif Rujukan

Sedangkan berikut adalah moodboard motif yang mempengaruhi pengembangan desain yang beru berupa simplified patterns, atau motif repetitif yang disederhanakan dengan dominasi warna netral yang dijadikan sebagai referensi visual.

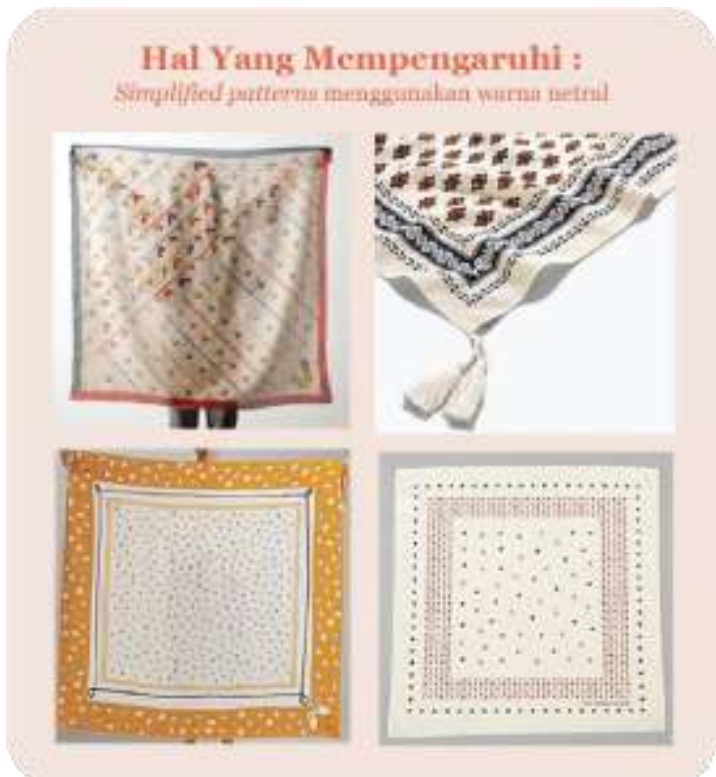

Gambar 8 : Moodboard Referensi Visual berupa Simplified Patterns dengan warna netral

2) Konsep Desain

Batik Nusantara seringkali dipandang sebelah mata oleh generasi muda jaman sekarang, terlebih dengan masuknya pengaruh budaya luar oleh arus globalisasi, kebudayaan lokal mulai ditinggalkan. Melalui penelitian pengembangan ini, desain motif yang sudah diberikan inovasi diharapkan dapat menyesuaikan selera pasar, terutama pada generasi milenial. Hal ini dilakukan dengan merancang konsep desain 
berupa memodifikasi motif batik tradisional menjadi lebih playful melalui permainan warna dan komposisi yang lebih modern dan sedang trend.

\section{Warna}

Kombinasi warna-warna terang yang menjadi ciri khas batik Lasem, yakni merah dan biru yang terang untuk menimbulkan kesan modern dan dipadupadankan dengan dominasi warna netral atau earthy tone seperti beige, putih, dan kuning.

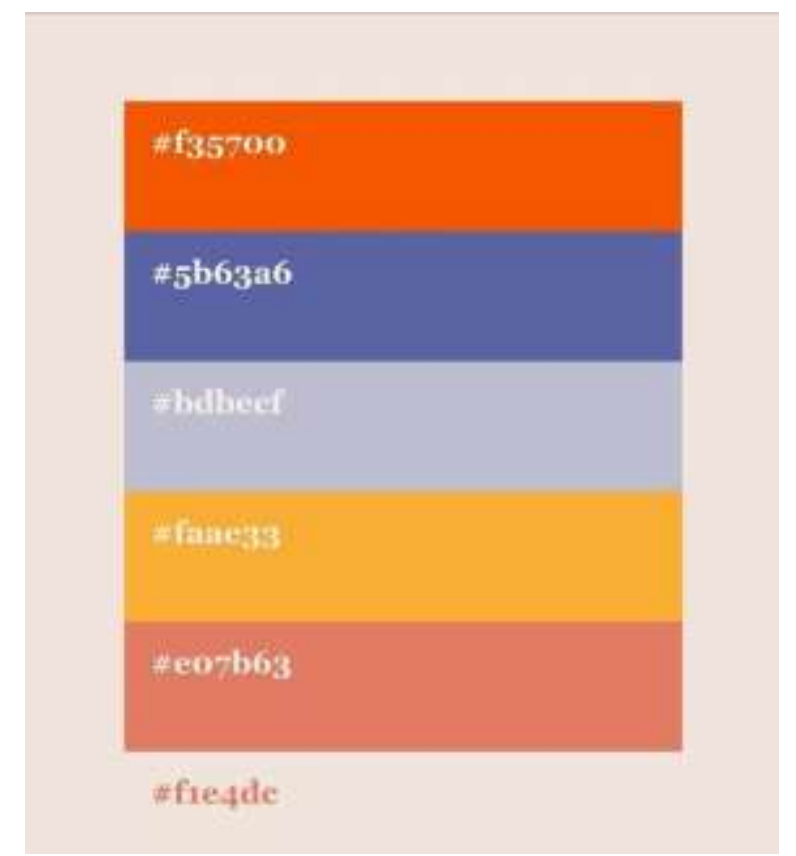

Gambar 9 : Palet warna yang digunakan

\section{Komposisi}

Batik Lasem terkenal dengan kerumitan dan kepadatan motifnya. Motif batik Lasem yang terkesan penuh akan diseimbangkan dengan motif repetitif yang ada pada kain modern yang kini banyak dijumpai. Dengan adanya 2 komposisi motif, yakni penuh dan clean yang disusun dalam bentuk diagonal akan menciptakan kesan motif kain yang seimbang.

\section{1) Pembuatan Sketsa}

Setelah konsep desain sudah ditentukan, langkah selanjutnya adalah pembuatan sketsa yang dilakukan secara digital. Sketsa dilakukan dengan membuat beberapa elemen yang merepresentasikan batik tulis Lasem seperti elemen burung hong, bunga teratai, sekar jagad, dan kupu-kupu. 


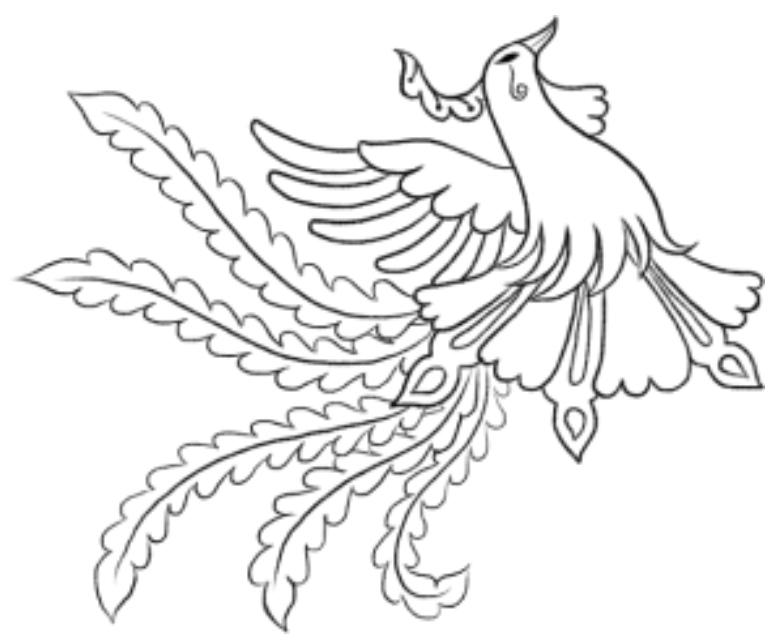

Gambar 9 : Elemen Burung Hong

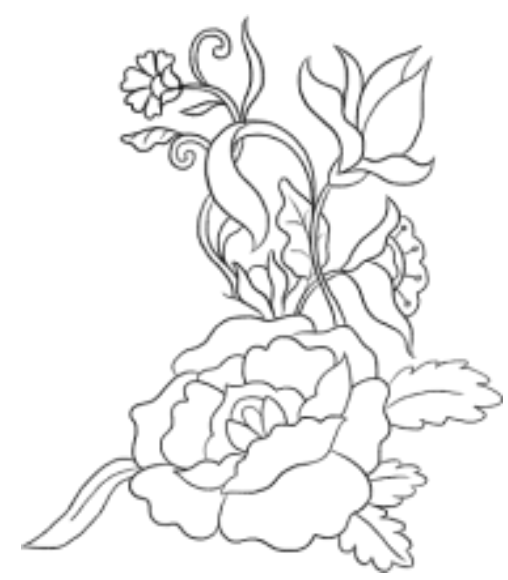

Gambar 10 : Elemen Bunga Sekar Jagad

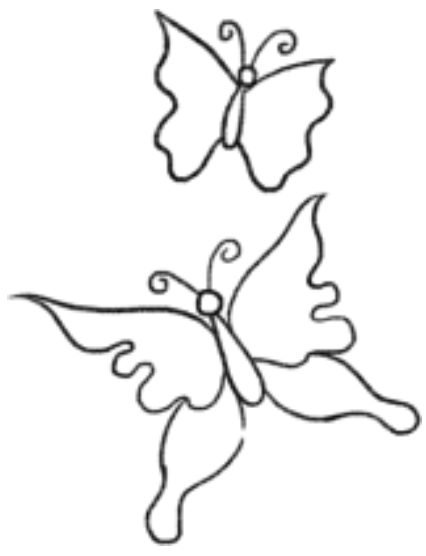

Gambar 11 : Elemen Kupu-Kupu 


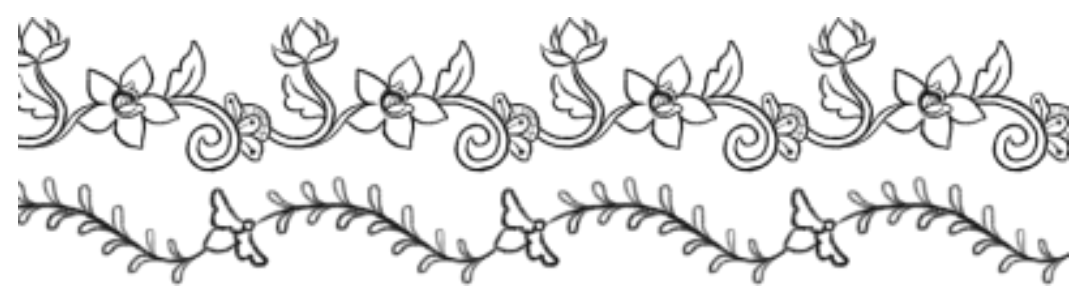

Gambar 12 : Pinggiran atau framing pada kain batik tulis Lasem

2) Penyusunan Komposisi Desain

Sketsa setiap elemen yang sudah dibuat kemudian disusun menjadi komposisi yang dikehendaki.

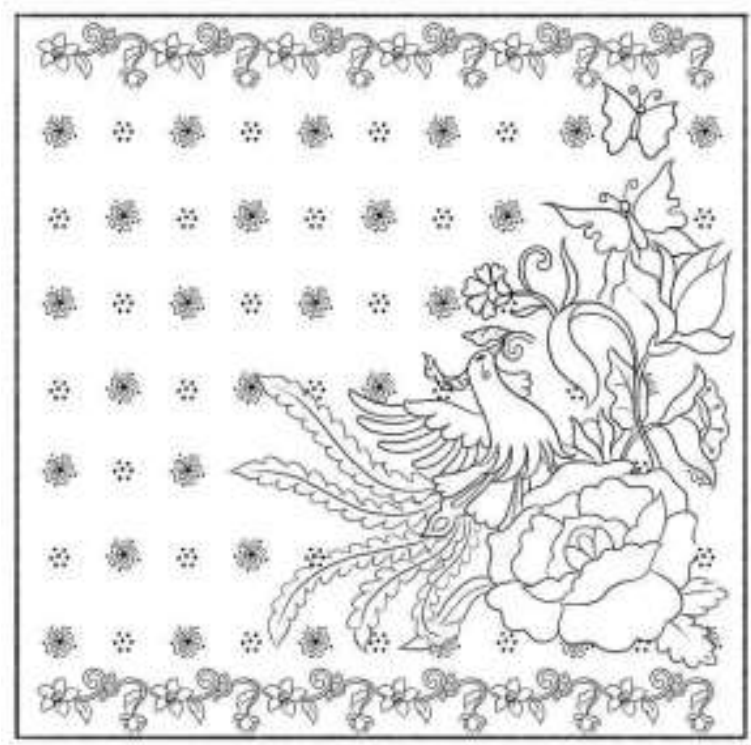

Gambar 13 : Sketsa Final

Sumber : Nabila Disarifianti, 2021

\section{Hasil Pengembangan Motif Batik Tulis Lasem}
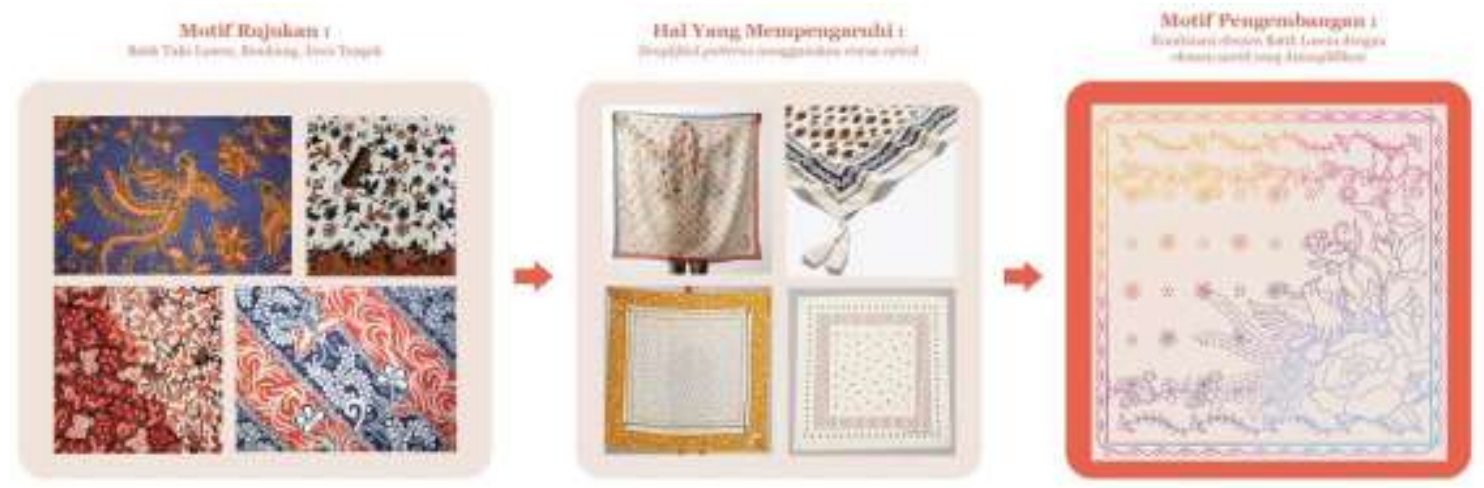

Gambar 15 : Diagram Moodboard Pengembangan Motif Batik Tulis Lasem 
Setelah melalui beberapa proses mulai dari mengumpulkan moodboard, Menyusun konsep desain, sketsa eksperimen, hingga eksekusi digital yang ditunjukkan oleh diagram moodboard di atas, berikut adalah hasil final pengembangan motif batik tulis Lasem.

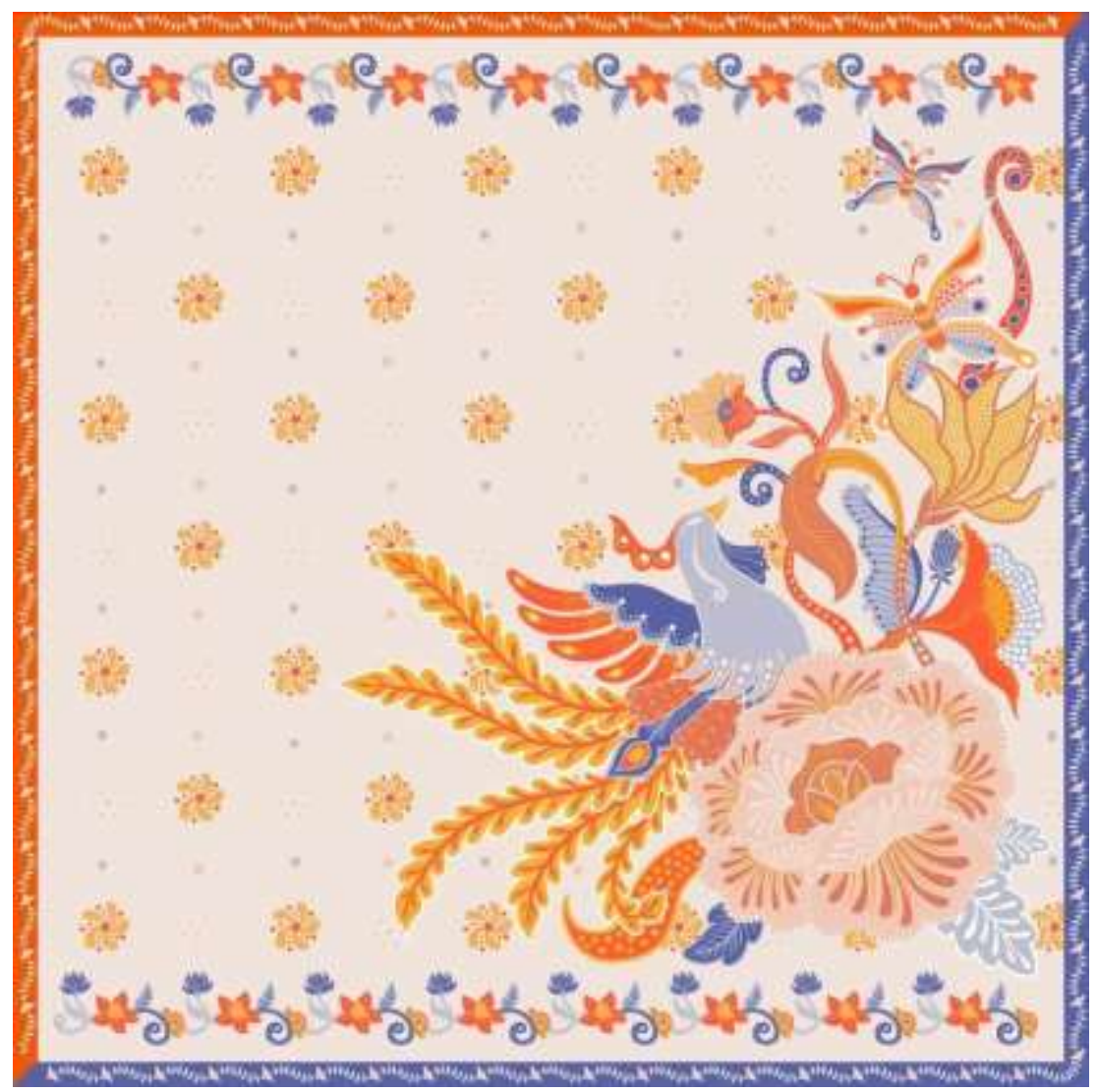

Gambar 16 : Hasil Final pengembangan motif batik tulis Lasem

Sumber : Nabila Disarifianti, 2021

\section{KESIMPULAN}

Berdasarkan penelitian pengembangan motif batik tulis Lasem yang telah dilakukan, dapat disimpulkan bahwa industri batik lokal dapat menggunakan strategi pemasaran produk dengan meningkatkan kualitas produk. Hal ini dapat dilakukan dengan mengembangkan serta memberikan inovasi terhadap produk. Selain itu, proses pengembangan produk yang menggunakan metode moodboard dinilai efektif dalam mengumpulkan informasi dan referensi visual karena dapat memetakan setiap referensi gambar dengan mudah. Dengan adanya motif batik Lasem yang sudah dikembangkan menjadi lebih modern ini, diharapkan dapat lebih beradaptasi dan diminati oleh selera pasar, terutama generasi milenial, sehingga kelestarian budaya Indonesia khususnya kain tradisional batik tetap dapat terjaga. 


\section{DAFTAR PUSTAKA}

Maghfiroh, Q., (2020). Bentuk Batik Tulis Lasem Motif Krecak di Perusahaan Batik Tulis Lasem Sekar Kencana. Jurnal Desain, 8(1), 61-75. Available at : http://dx.doi.org/10.30998/jd.v8i1.7780

Maulany, N. N., \& Masruroh, N. N., (2017). Kebangkitan Industri Batik Lasem di Awal Abad XXI. Patrawidya, 18(1), 1-14. Available at : https://core.ac.uk/download/pdf/84728202.pdf

Murwati, E. S., \& Masiswo (2013). Rekayasa Pengembangan Desain Motif Batik Khas Melayu. Dinamika Kerajinan dan Batik, 30(2), 1-6. Available at : https://media.neliti.com/media/publications/61328-ID-rekayasa-pengembangandesain-motif-batik.pdf

Noviani, L., Wahida, A., \& Tamrin, AG., (2015). Pengembangan Desain Motif Kain Tenun Goyor. Inotek, 19(1), 1-8. Available at : https://journal.uny.ac.id/index.php/inotek/article/download/5143/4439

Syahrial, Mario Fahmi., (2019). Strategi Pemasaran Pengrajin Batik Tulis Lasem di Desa Wisata Batik Tulis Babagan Lasem Kecamatan Lasem. Jurnal Ilmiah Pendidikan Ekonomi, 4(1), 1-7. Available at : http://journal.upgris.ac.id/index.php/equilibriapendidikan

Anggarini, A., Bangun, Dwi A. N., \& Saripudin, Irpan., (2020). Alternatif Model Penyusunan Mood Board Sebagai Metode Berpikir Kreatif Dalam Pengembangan Konsep Visual. Journal Printing and Packaging Technology, 1(1), 1-7. Available at : http://jurnal.pnj.ac.id/index.php/ppt/article/view/2455

Garner, Mc Donagh-Philp. 2001. Problem Interpretation and Resolution via Visual Stimuli : The Use of 'Moodboard' in Design Education. The International Journal of Art and Design Education, 20(1), 57 - 64. Available at : https://doi.org/10.1111/1468$\underline{5949.00250}$

Kemenparekraf Baparekraf RI . (2020). Industri Batik Perlu Didukung untuk Tingkatkan Ekonomi. [Online] https://pedulicovid19.kemenparekraf.go.id/. Available at : https://pedulicovid19.kemenparekraf.go.id/industri-batik-perlu-didukung-untuktingkatkan-ekonomi/

Batik.or.id . (2017). Batik Lasem. [Online] batik.or.id. Available at : https://batik.or.id/batik-lasem/ 